\title{
Antibacterial Effect of Silver Nanoparticles along with L-Arginine against $P$. aeruginosa
}

Mina Parsa (MSc)

Department of Microbiology, Faculty of Veterinary Medicine, Urmia University, Urmia, Iran

Malahat Ahmadi (PhD)

Professor of Bacteriology, Department of Microbiology, Faculty of Veterinary Medicine, Urmia University, Urmia, Iran

Habib Dastmalchi (PhD)

Department of Microbiology, Faculty of Veterinary Medicine, Urmia

University, Urmia, Iran

Aliasghar Tehrani (PhD)

Department of Pathology, Faculty of

Veterinary Medicine, Urmia

University, Urmia, Iran

Email: mi.parsa27@gmail.com

Tel: +989143406410

Address: Faculty of Veterinary Medicine, Urmia University, Urmia, Iran

Received : 11 Feb 2017

Revised: 09 May 2017

Accepted: 29 May 2017

\section{ABSTRACT}

Background and Objectives: Nowadays, the prevalence of multidrug-resistant pathogens such as Pseudomonas aeruginosa is increasing worldwide. Many studies have been seeking new treatment strategies to treat infections caused by these microorganisms. Silver nanoparticles (AgNPs) along with L-arginine have significant antimicrobial effects and could be used as alternatives for ineffective drugs.

Methods: In this study, the antibacterial activity of AgNPs, L-arginine and various concentrations of AgNPs along with L-arginine (12.5 and $25 \mathrm{mg} / \mathrm{ml}$ ) were investigated against $P$. aeruginosa PA01 using the broth macrodilution method.

Results: Minimum inhibitory concentration of AgNPs, L-arginine and AgNPs combined with 25 and $12.5 \mathrm{mg} / \mathrm{ml} \mathrm{L-arginine} \mathrm{was} 15.6 \mu \mathrm{g} / \mathrm{ml}, 25 \mathrm{mg} / \mathrm{ml}, 1.9 \mu \mathrm{g} / \mathrm{ml}$ and $3.9 \mu \mathrm{g} / \mathrm{ml}$, respectively. Minimum bactericidal concentration of AgNPs, L-arginine and AgNPs combined with 25 and $12.5 \mathrm{mg} / \mathrm{ml} \mathrm{L-arginine} \mathrm{was} 31.2 \mu \mathrm{g} / \mathrm{ml}, 50 \mathrm{mg} / \mathrm{ml}, 3.9 \mu \mathrm{g} / \mathrm{ml}$ and $7.8 \mu \mathrm{g} / \mathrm{ml}$, respectively.

Conclusion: 0ur study suggests that AgNPs along with L-arginine can be used as an alternative antibacterial agent against $P$. aeruginosa, and might be useful for treatment of wound infections.

Keywords: Nanoparticles, Arginine, Anti-Bacterial Agents, Pseudomonas aeruginosa. 


\section{INTRODUCTION}

Nowadays, the prevalence of multidrugresistant pathogens such as Pseudomonas aeruginosa is on the rise (1). P. aeruginosa is involved in several infections such as urinary tract infection, pneumonia, meningitis and soft tissue infections $(2,3)$. Infections caused by resistant pathogens may increase the risk of treatment failure and severity of the disease (4). Resistance mechanisms in bacteria could be due to the indiscriminate use of drugs, ineffective infection control programs (5-7) and lack of novel therapeutic strategies against pathogens, especially $P$. aeruginosa $(8,9)$. Several studies have been conducted to develop new generation of drugs in order to overcome the threat posed by multidrugresistant pathogens $(10,11)$. In this regard, silver nanoparticles (AgNPs) have been proposed as suitable alternatives that have good physicochemical and biological properties. They are simple to use, affordable and widely applicable in a variety of antibacterial methods (12). AgNPs also have acceptable antimicrobial activity (13-15) and high biocompatibility with far lower propensity to induce microbial resistance compared to current drugs. Due to these unique properties, these materials could be used as effective alternatives for elimination of multidrug resistant microorganisms (16-19).

L-arginine is an $\alpha$-amino acid with antibacterial activity that has important roles in wound healing and urea cycle (20). The positive charge of L-arginine attract the negatively charged target membranes such as LPS in Gram-negative bacteria or teichoic acid in Gram-positive bacteria and phospholipid head groups (21). Because of the antibacterial effects of nanoparticles and L-arginine and also high tendency of arginine towards silver ions, it can be predicted that the silverarginine complex show broader spectrum of antimicrobial effects (22, 23). Although AgNPs may have cytotoxic effects on host cell (24), these effects can be reduced by altering the therapeutic doses (25). Thus, reducing the concentration of nanoparticles via combination with L-arginine can be effective in minimizing the toxic effects of nanoparticles. Considering the limited number of studies on the interaction between arginine and metal ions (23), the present study evaluated the antibacterial activity of AgNPs along with
L- arginine against $P$. aeruginosa in an aqueous system.

\section{MATERIAL AND METHODS}

Subsequent dilutions $(0.2$ to $500 \mu \mathrm{g} / \mathrm{ml})$ of colloidal AgNPs (average size $20 \mathrm{~nm}$, Pishgaman Nano Arya Co.) were prepared in Muller Hinton broth from stock solution. Stock solution of L-arginine (Merck, Germany) was prepared in distilled water with final concentration of $200 \mathrm{mg} / \mathrm{ml}$, and later used to prepare subsequent dilutions (0.1 to $100 \mathrm{mg} / \mathrm{ml}$ ) in Muller Hinton broth, using serial two-fold dilution. Subsequent dilutions of AgNPs $(0.2-500 \mu \mathrm{g} / \mathrm{ml})$ were prepared in Muller Hinton broth. Two concentrations of Larginine $(12.5$ and $25 \mathrm{mg} / \mathrm{ml})$ were separately added to each tube.

$P$. aeroginosa PAO1 was obtained from Urmia University of Medical Sciences. The bacteria were grown in Muller Hinton broth at $37{ }^{\circ} \mathrm{C}$ for $24 \mathrm{~h}$. Bacterial suspension equivalent to 0.5 McFarland standard $\left(1.5 \times 10^{8} \mathrm{CFU} / \mathrm{ml}\right)$ was prepared in sterile normal saline (26).

Determination of minimal inhibitory concentration (MIC) and minimal bactericidal concentration $(\mathrm{MBC})$

The MIC of AgNPs, L-arginine and AgNPs with L-arginine against $P$. aeroginosa was determined by broth macrodilution method according to the Clinical and Laboratory Standards Institute (CLSI, 2014).

Determination of MIC and MBC of AgNPs and L-arginine

Different concentrations of $(0.2-500 \mu \mathrm{g} / \mathrm{ml})$ of AgNPs were prepared in Muller Hinton broth using two fold serial dilutions. Bacterial suspension containing $1.5 \times 10^{8} \mathrm{CFU} / \mathrm{ml}$ was added to each tube, and the tubes were incubated at $37{ }^{\circ} \mathrm{C}$ for $24 \mathrm{~h}$. The MIC was defined as the lowest concentration of AgNPs that was able to inhibit bacterial growth. The dilution method was also used to determine MBC values. For this propose, $100 \mu \mathrm{l}$ of bacterial suspension containing $\geq \mathrm{MIC}$ concentrations of AgNPs were cultured on Muller Hinton agar plates. After incubation at $37^{\circ} \mathrm{C}$ for $24 \mathrm{~h}$, the MBC value was defined as the lowest concentration of AgNPs that was able to kill $99.9 \%$ of bacteria. All experiments were performed in triplicate, on three different days (27). The MIC and MBC values for Larginine were determined using the method 
described for AgNPs by preparing different concentrations (100- $0.1 \mathrm{mg} / \mathrm{ml})$ of L-arginine in Muller Hinton broth using two fold serial dilutions.

Determination of MIC and MBC of AgNPS along with L-arginine

First, bacterial suspension $\left(1.5 \times 10^{8} \mathrm{CFU} / \mathrm{ml}\right)$ was added to tubes containing AgNPs along with $\mathrm{L}$-arginine. The tubes were incubated at $37^{\circ} \mathrm{C}$ for $24 \mathrm{~h}$. MIC and MBC of AgNPs along with $\mathrm{L}$-arginine was determined using the method described for AgNPs and L-arginine. All experiments were performed in triplicate, on three different days.

\section{RESULTS}

The MIC of AgNPs, L-arginine and AgNPs along with two different concentrations $(25 \mathrm{mg} / \mathrm{ml}$ and $12.5 \mathrm{mg} / \mathrm{ml})$ of L-arginine was $15.6 \mu \mathrm{g} / \mathrm{ml}, 25 \mu \mathrm{mg} / \mathrm{ml}, 1.9$ $\mu \mathrm{g} / \mathrm{ml}$ and $3.9 \mu \mathrm{g} / \mathrm{ml}$, respectively. The MBC of AgNPs, L-arginine and AgNPs along with L-arginine $(25 \mathrm{mg} / \mathrm{ml}$ and $12.5 \mathrm{mg} / \mathrm{ml})$ were $31.2 \mu \mathrm{g} / \mathrm{ml}, 50 \mathrm{mg} / \mathrm{ml}, 3.9 \mu \mathrm{g} / \mathrm{ml}$ and 7.8 $\mu \mathrm{g} / \mathrm{ml}$, respectively (Table 1 ). Overall, the 20 $\mathrm{nm}$ AgNPs and L-arginine showed antibacterial activity against $P$. aeruginosa strain PAO1. The addition of $25 \mathrm{mg}$ (MIC value) and $12.5 \mathrm{mg}$ (MIC50 value) of Larginine to various concentrations of AgNPs increased the antibacterial activity.

Table 1 -MIC and MBC values of AgNPs, L- arginine and AgNPs along with $L$ - arginine against $P$. aeruginosa

\begin{tabular}{ccc}
\hline Drug & MIC $(\mu \mathrm{g} / \mathrm{ml})$ & MBC $(\mu \mathrm{g} / \mathrm{ml})$ \\
\hline AgNPs $(\mu \mathrm{g} / \mathrm{ml})$ & 15.6 & 31.2 \\
L-arginine $(\mathrm{mg} / \mathrm{ml})$ & 25.0 & 50.0 \\
NPs $+25 \mathrm{mg} / \mathrm{ml}$ L-arginine & 1.9 & 3.9 \\
NPs $+12.5 \mathrm{mg} / \mathrm{ml}$ L-arginine & 3.9 & 7.8 \\
\hline
\end{tabular}

\section{DISCUSSION}

Considering the growing prevalence of multidrug-resistant microorganisms and the subsequent increase in therapeutic expenses, several studies have sought safe treatment strategies to overcome antibiotic resistance (28). In recent years, nanoparticles have been extensively used in drug delivery (29) and therapies (30). Several recent studies have shown the antimicrobial applications of AgNPs (31-33). Although their mechanism of action is not yet clear, some studies have reported the positive charge of nanoparticles (34-36) and the excess production of free radicals on the surface of $\mathrm{Ag}$ (37) as the main inhibitory mechanisms. In the present study, we assessed the antibacterial effect of different concentrations of 20-nm AgNPs alone and along with L-arginine against $P$. aeroginosa PAO1 using broth macrodilution method. Our results showed that AgNPs had good antibacterial activity at concentration of 15.6 $\mu \mathrm{g} / \mathrm{ml}$. Similar to our study, many studies have demonstrated the antibacterial effect of AgNPs on Gram-positive and Gram-negative bacteria (38-40). Although AgNPs had good antibacterial effects, they may also cause significant cytotoxicity (33). In fact, finding a material with excellent antimicrobial properties and very low toxicity on the host cells is challenging (41). The cytotoxic effects of AgNPs depend on some factors including dose, size and shape (42). Fidel MartinezGutierrez reported that $24 \mathrm{~nm}$ of AgNPs has dose-dependent cytotoxic effects. Concentrations $\leq 6.25 \mu \mathrm{g} / \mathrm{ml}$ of AgNPs had minimal cytotoxic effects on macrophages. Whereas, concentrations $\geq 12.5 \mu \mathrm{g} / \mathrm{mL}$ exhibited significant cytotoxic effects and almost killed 50\% of macrophages (33). In the present study, we used AgNPs along with Larginine to increase the antibacterial effect of AgNPs and reduce their toxicity. L-arginine is a vital amino acid for wound healing and fracture healing $(43,44)$. The peptides rich in arginine have high antimicrobial activities, which is due to its interaction with bacterial cell wall $(45,46)$. A few studies have evaluated the antibacterial effect of L-arginine (23, 47, 48). Deepa et al. evaluated the antibacterial effects of L-arginine/Ltryptophan, D-arginine/D-tryptophan and Lleucien/L-arginine on several woundassociated bacteria, and reported that all three dipeptides have antibacterial properties and synergistic effects when combined with ampicillin (47). In our study, L-arginine had antibacterial effects at concentration of 25 $\mathrm{mg} / \mathrm{ml}$, but addition of the MIC and MIC50 concentrations of L-arginine increased the antibacterial effect of AgNPs. The MIC 
of AgNPs with L-arginine were 3.9 and 1.9 $\mu \mathrm{g} / \mathrm{ml}$,. Therefore, it can be concluded that Larginine had synergistic effects on AgNPs. Furthermore, L-arginine is a non-enzymatic antioxidant that can reduce the toxic effects of nanoparticles (49). Takayama et al. reported that L-arginine-silvernitrate had antibacterial effects against Escherichia coli, Bacillus subtilis, Staphylococcus aureus, and $P$. aeruginosa (23), which is consistent with our study. Tang et al. also reported that Larginine-chitosan had significant inhibitory effect on $P$. florosence and E. coli (50). Further studies should be performed to examine the toxic effects of AgNPs and Larginine on human cells in vivo.

\section{REFERENCES}

1. Oliver A, Mulet X, López-Causapé C, Juan C. The increasing threat of Pseudomonas aeruginosa high-risk clones. Drug Resistance Updates. 2015; 22: 41-59. doi: 10.1016/j.drup.2015.08.002.

2. Kerr KG, Snelling AM. Pseudomonas aeruginosa: a formidable and ever-present adversary. Journal of Hospital Infection. 2009; 73(4): 338-44. doi: 10.1016/j.jhin.2009.04.020

3. Williamson KS, Richards LA, Perez-Osorio AC, Pitts B, McInnerney K, Stewart PS, et al. Heterogeneity in Pseudomonas aeruginosa biofilms includes expression of ribosome hibernation factors in the antibiotic-tolerant subpopulation and hypoxia-induced stress response in the metabolically active population. Journal of bacteriology. 2012; 198(4): 2062-73. doi: 10.1128/JB.00022-12.

4. Yazah A, Yusuf J, Agbo A. Bacterial contaminants of Nigerian currency notes and associated risk factors. Research Journal of Medical Sciences. 2012; 6(1): 1-6. DOI: 10.3923/rjmsci.2012.1.6.

5. Carlet J, Jarlier V, Harbarth S, Voss A, Goossens H, Pittet D. Ready for a world without antibiotics? The pensières antibiotic resistance call to action. Antimicrobial resistance and infection control. 2012;1(1):11.

6. Lerner A, Adler A, Abu-Hanna J, Percia SC, Matalon MK, Carmeli Y. Spread of KPC-producing carbapenemresistant Enterobacteriaceae: the importance of superspreaders and rectal KPC concentration. Clinical Microbiology and Infection. 2015; 21(5): 470. e1-. e7. doi: 10.1016/j.cmi.2014.12.015.

7. Hawkey P. Multidrug-resistant Gram-negative bacteria: a product of globalization. Journal of Hospital Infection. 2015;89(4):241-7. doi: 10.1016/j.jhin.2015.01.008.

8. Livermore D. The need for new antibiotics. Clinical Microbiology and Infection. 2004; 10(s4):1-9.

9. Talbot GH, Bradley J, Edwards JE, Gilbert D, Scheld M, Bartlett JG. Bad bugs need drugs: an update on the development pipeline from the Antimicrobial Availability Task Force of the Infectious Diseases Society of America. Clinical infectious diseases. 2006; 42(5): 657-68. DOI: $10.1086 / 499819$

10. Mulvey MR, Simor AE. Antimicrobial resistance in hospitals: how concerned should we be? Canadian Medical Association Journal. 2009; 180(4): 408-15. doi: 10.1503/cmaj.080239.

\section{CONCLUSION}

Our study suggests that AgNPs along with L-arginine can be used as an alternative antibacterial agent against $P$. aeruginosa, and might be useful for treatment of wound infections.

\section{ACKNOWLEDGMENTS}

The authors acknowledge the Urmia University for their financial support in this study.

\section{CONFLICT OF INTEREST}

The authors declare that there is no conflict of interest.

11. Otter JA, French GL. Nosocomial transmission of community-associated meticillin-resistant Staphylococcus aureus: an emerging threat. The Lancet infectious diseases. 2006; 6(12): 753-5. DOI:10.1016/S1473-3099(06)70636-3.

12. Kim JS, Kuk E, Yu KN, Kim J-H, Park SJ, Lee HJ, et al. Antimicrobial effects of silver nanoparticles. Nanomedicine: Nanotechnology, Biology and Medicine. 2007; 3(1): 95-101. DOI:10.1016/j.nano.2006.12.001

13. Martinez-Gutierrez F, Olive PL, Banuelos A, Orrantia E, Nino N, Sanchez EM, et al. Synthesis, characterization, and evaluation of antimicrobial and cytotoxic effect of silver and titanium nanoparticles. Nanomedicine: Nanotechnology, Biology and Medicine. 2010; 6(5): 681-8. doi: 10.1016/j.nano.2010.02.001.

14. Lok C-N, Ho C-M, Chen R, He Q-Y, Yu W-Y, Sun H, et al. Silver nanoparticles: partial oxidation and antibacterial activities. JBIC Journal of Biological Inorganic Chemistry. 2007; 12(4): 527-34. DOI:10.1007/s00775-007-0208-z.

15. Morones JR, Elechiguerra JL, Camacho A, Holt K, Kouri JB, Ramírez JT, et al. The bactericidal effect of silver nanoparticles. Nanotechnology. 2005; 16(10): 2346. doi: 10.1088/0957-4484/16/10/059.

16. Rai M, Yadav A, Gade A. Silver nanoparticles as a new generation of antimicrobials. Biotechnology advances. 2009; 27(1): 76-83.

17. Eckhardt S, Brunetto PS, Gagnon J, Priebe M, Giese B, Fromm KM. Nanobio silver: its interactions with peptides and bacteria, and its uses in medicine. Chemical reviews. 2013; 113(7): 4708-54. DOI: 10.1021/cr300288v.

18. Lewinski N, Colvin V, Drezek R. Cytotoxicity of nanoparticles. $\quad$ small. 2008; 4(1): 26-49. doi: 10.1002/smll.200700595.

19. Braydich-Stolle L, Hussain S, Schlager JJ, Hofmann MC. In vitro cytotoxicity of nanoparticles in mammalian germline stem cells. Toxicol Sci. 2005; 88(2): 412-9. DOI:10.1093/toxsci/kfi256.

20. Morris SM. Arginine: beyond protein. The American journal of clinical nutrition. 2006; 83(2): 508S-12S.

21. Jing W, Demcoe AR, Vogel HJ. Conformation of a bactericidal domain of puroindoline a: structure and mechanism of action of a 13-residue antimicrobial peptide. Journal of bacteriology. 2003; 185(16): 4938-47. 
22. Agnihotri S, Bajaj G, Mukherji S, Mukherji S. Arginineassisted immobilization of silver nanoparticles on $\mathrm{ZnO}$ nanorods: an enhanced and reusable antibacterial substrate without human cell cytotoxicity. Nanoscale. 2015; 7(16): 7415-29. doi: 10.1039/c4nr06913g.

23. Takayama A, Yoshikawa R, Iyoku S, Kasuga NC, Nomiya K. Synthesis, structure and antimicrobial activity of L-argininesilver $(1+)$ nitrate. Polyhedron. 2013; 52: 844-7. DOI: $10.1016 /$ j.poly.2012.07.031.

24. Zhang T, Wang L, Chen Q, Chen C. Cytotoxic potential of silver nanoparticles. Yonsei Med J. 2014; 55(2): 283-91. doi: 10.3349/ymj.2014.55.2.283.

25. Chernousova S, Epple M. Silver as antibacterial agent: ion, nanoparticle, and metal. Angewandte Chemie International Edition. 2013; 52(6): 1636-53. DOI: 10.1002/anie.201205923.

26. Spange S, Pfuch A, Wiegand C, Beier O, Hipler UC, Grünler B. Atmospheric pressure plasma CVD as a tool to functionalise wound dressings. Journal of Materials Science: Materials in Medicine. 2015; 26(2): 1-9. doi: 10.1007/s10856-015-5417-3.

27. Institute CLS. Document S100-S24 Performance standards for antimicrobial susceptibility testing; twenty-fourth informationalsupplement. 2014.

28. Jones SA, Bowler PG, Walker M, Parsons D.

Controlling wound bioburden with a novel silver-containing Hydrofiber ${ }^{\circledR}$ dressing. Wound Repair and Regeneration. 2004; 12(3): 288-94. DOI:10.1111/j.1067-

1927.2004.012304.x.

29. Meng H, Liong M, Xia T, Li Z, Ji Z, Zink JI, et al. Engineered design of mesoporous silica nanoparticles to deliver doxorubicin and P-glycoprotein siRNA to overcome drug resistance in a cancer cell line. ACS nano. 2010; 4(8): 4539-50. doi: 10.1021/nn100690m.

30. Godin B, Sakamoto JH, Serda RE, Grattoni A, Bouamrani A, Ferrari M. Emerging applications of nanomedicine for the diagnosis and treatment of cardiovascular diseases. Trends in pharmacological sciences. 2010; 31(5): 199-205. doi: 10.1016/j.tips.2010.01.003.

31. Ivask A, ElBadawy A, Kaweeteerawat C, Boren D, Fischer H, Ji Z, et al. Toxicity mechanisms in Escherichia coli vary for silver nanoparticles and differ from ionic silver. Acs Nano. 2013; 8(1): 374-86. DOI: 10.1021/nn4044047.

32. Tran QH, Le AT. Silver nanoparticles: synthesis, properties, toxicology, applications and perspectives. Advances in Natural Sciences: Nanoscience and Nanotechnology. 2013; 4(3): 033001. DOI:10.1088/20436262/4/3/033001.

33. Martínez-Gutierrez F, Thi EP, Silverman JM, de Oliveira $\mathrm{CC}$, Svensson SL, Hoek AV, et al. Antibacterial activity, inflammatory response, coagulation and cytotoxicity effects of silver nanoparticles. Nanomedicine. 2012; 8(3): 328-36. doi: 10.1016/j.nano.2011.06.014.

34. Hamouda T, Myc A, Donovan B, Shih AY, Reuter JD, Baker JR. A novel surfactant nanoemulsion with a unique non-irritant topical antimicrobial activity against bacteria, enveloped viruses and fungi. Microbiological research. 2001; 156(1): 1-7.

35. Dibrov P, Dzioba J, Gosink KK, Häse CC. Chemiosmotic mechanism of antimicrobial activity of Ag+ in Vibrio cholerae. Antimicrobial agents and chemotherapy. 2002; 46(8): 2668-70. doi: 10.1128/AAC.46.8.26682670.2002 .

36. Dragieva I, Stoeva S, Stoimenov P, Pavlikianov E, Klabunde K. Complex formation in solutions for chemical synthesis of nanoscaled particles prepared by borohydride reduction process. Nanostructured materials. 1999; 12(1-4):
267-70. DOI: 10.1016/S0965-9773(99)00114-2.

37. Mendis E, Rajapakse N, Byun H-G, Kim S-K. Investigation of jumbo squid (Dosidicus gigas) skin gelatin peptides for their in vitro antioxidant effects. Life Sciences. 2005; 77(17): 2166-78. DOI:10.1016/j.lfs.2005.03.016.

38. Quinteros MA, Aiassa Martínez IM, Dalmasso PR, Páez PL. Silver nanoparticles: biosynthesis using an ATCC reference strain of Pseudomonas aeruginosa and activity as broad spectrum clinical antibacterial agents. International Journal of Biomaterials. 2016; ID 5971047.

39. Aliakbar N, Roghayeh AG, Seyed Ali N, Majidreza A, Sharareh H, Masoud A, et al. Evaluation of the Antimicrobial Activity of Silver Nanoparticles on AntibioticResistant Pseudomonas aeruginosa. International Journal of Basic Science in Medicine. 2016; 1(1): 25-8. DOI:10.15171/ijbsm.2016.06.

40. Guzman M, Dille J, Godet S. Synthesis and antibacterial activity of silver nanoparticles against gram-positive and gram-negative bacteria. Nanomedicine: Nanotechnology, Biology and Medicine. 2012; 8(1): 37-45. doi: 10.1016/j.nano.2011.05.007.

41. Silver S. Bacterial silver resistance: molecular biology and uses and misuses of silver compounds. FEMS microbiology reviews. 2003; 27(2-3): 341-53.

42. Luther EM, Koehler Y, Diendorf J, Epple M, Dringen R. Accumulation of silver nanoparticles by cultured primary brain astrocytes. Nanotechnology. 2011; 22(37): 375101. doi: 10.1088/0957-4484/22/37/375101.

43. Sinha S, Goel SC. Effect of amino acids lysine and arginine on fracture healing in rabbits: A radiological and histomorphological analysis. Indian journal of orthopaedics. 2009; 43(4): 328-334. doi: 10.4103/0019-5413.55972.

44. Debats IB, Wolfs TG, Gotoh T, Cleutjens JP, PeutzKootstra CJ, van der Hulst RR. Role of arginine in superficial wound healing in man. Nitric Oxide. 2009; 21(34): 175-83. doi: 10.1016/j.niox.2009.07.006.

45. Blondelle SE, Houghten RA. Novel antimicrobial compounds identified using synthetic combinatorial library technology. Trends in biotechnology. 1996; 14(2): 60-5. DOI:10.1016/0167-7799(96)80922-X.

46. Jiang B, Larson JC, Drapala PW, Pérez-Luna VH, KangMieler JJ, Brey EM. Investigation of lysine acrylate containing poly ( $N$-isopropylacrylamide) hydrogels as wound dressings in normal and infected wounds. J Biomed Mater Res B Appl Biomater. 2012; 100(3): 668-76. doi: 10.1002/jbm.b.31991.

47. Deepa I, Kumar SN, Sreerag RS, Nath VS, Mohandas C. Purification and synergistic antibacterial activity of arginine derived cyclic dipeptides, from Achromobacter $s p$. associated with a rhabditid entomopathogenic nematode against major clinically relevant biofilm forming wound bacteria. Frontiers in microbiology. 2015; 6: 876. doi: 10.3389/fmicb.2015.00876.

48. Chan DI, Prenner EJ, Vogel HJ. Tryptophan-and arginine-rich antimicrobial peptides: structures and mechanisms of action. Biochimica et Biophysica Acta (BBA)-Biomembranes. 2006; 1758(9): 1184-202. DOI:10.1016/j.bbamem.2006.04.006.

49. Rahimi R, Nikfar S, Larijani B, Abdollahi M. A review on the role of antioxidants in the management of diabetes and its complications. Biomed Pharmacother. 2005; 59(7): 365-73. DOI:10.1016/j.biopha.2005.07.002.

50. Tang H, Zhang P, Kieft TL, Ryan SJ, Baker SM, Wiesmann WP, et al. Antibacterial action of a novel functionalized chitosan-arginine against Gram-negative bacteria. Acta Biomater. 2010; 2562-71. doi: 10.1016/j.actbio.2010.01.002. 